\title{
Conducting safety analysis and simulations for protection of a delivery electric system with essential power consumers
}

\author{
Mariana Dumitrescu ${ }^{1 *}$ \\ ${ }^{1}$ University Dunarea de Jos, Automation and Electric Engineering Department, Stiintei 02, Galati, \\ Romania
}

\begin{abstract}
The paper presents a real power delivery system with essential consumers safety analysis. The two levels voltage networks $6 \mathrm{kV}$ and $0,4 \mathrm{kV}$ are modeled with the help of Edsa software and short-circuit simulation is conducted in order to obtain the computed values of the currents to all the network buses. The results are used to implement a technical solution for an important safety improvement of the analysed system.
\end{abstract}

\section{Introduction}

The main abnormal regimes encountered in electric power installations are overcurrents, voltage drops, frequency drops and overvoltages [1-3].

Overcurrents are caused by short circuits outside the protected element or by the occurrence of an overload. Overcurrents do not cause an immediate disconnection of the protected element, but if no action is taken against them, they can cause the conductors overheat and therefore damage their insulation, which can lead to a short circuit.

Voltage drops are caused by short circuits outside the protected area, which lead to voltage drops at the buses of the electric stations close to the fault. These abnormal regimes have more effects on electric motors, reducing their speed or even in some cases stopping them. The decrease in frequency is due to the sudden increase in power consumption, which affects the operation of mechanisms and equipment driven by electric motors. Overvoltages can appear for example by supplying a consumer with a capacitive reactance.

In the case of the electrical distribution stations, faults on the connection buses can be single-phase or multi-phase. Single-phase short circuits can appear only to the networks buses with neutral point connected to the ground. In the case of networks with isolated neutral point, the contacts between a phase and earth, do not represent short circuits, but abnormal operating regimes.

The most common defects are single-phase short circuits caused by atmospheric overvoltages, that cause the internal insulation failure or the surface isolator failure due to impurities that settle on their surface. Other common faults are polyphase short circuits, caused by electrical equipment failures or maneuvering errors.

\footnotetext{
${ }^{*}$ Corresponding author: mariana.dumitrescu@ugal.ro
} 
The consequences of short circuits on the buses are serious, because there are very high short-circuit currents with important thermal and electrodynamic effects, which cause significant damage to installations. Also, the short circuit on the buses leads to the disconnection of all connected equipment: generators, transformers, transmission lines, interconnection lines or distribution lines. For this reason, protections with multifunctional relay are needed to act safely and quickly to locate and liquidate the defects [2-4].

The operating principle of a multifunctional relay is based on the collection of current and voltage information by means of current and voltage measuring transformers, mounted on the power supply system and / or on the consumer. The information from the measuring transformers reaches the internal circuits that perform the motor protection. These circuits are made up of logic blocks, constructed in such a way that they can send a breaker opening signal to interrupt the power supply, when a fault occurs on the supply line or even inside the equipment, $[3,5,6]$.

In addition of providing protection, the multifunctional relay can also provide information on active and reactive power, current, voltage, power factor, frequency. It has a memory circuit where you can store defects that have occurred in recent months and you can access them to decide if the equipment can still work [7, 8].

Section 1 describe the delivery analyzed power system, section shows how the shortcircuit analysis is conducted, section 3 gives the safety protection measures for the analyzed power system.

\section{Delivery electric system with essential consumers}

The analyzed power system (Figure 1) has 2 electric substations 1, 2 and is connected to the national grid system $110 \mathrm{kV}$, through the main transformer station with two redundant $110 / 6 \mathrm{kV}$ transformers and the $6 \mathrm{kV}$ busbars 1,2 and Transfer, located on the Galati Liberty Still factory platform.

From each of these $6 \mathrm{kV}$ buses 1,2 are supplied two secondary stations, buses 3, 4 Station 1, buses 5, 6, 7 -Station 2. From the redundant buses 3, 4 are supplied the air compressors M1, M2, M3 and the transformers T3, T4 which step down the voltage to $0,4 \mathrm{kV}$ ( they supply $400 \mathrm{~V}$ busbars 8,9 for the asynchronous motors M9, M10). The buses 5, 6, 7 supply 3 synchronous motors and 2 transformers which step down the voltage to $0,4 \mathrm{kV}$ for other 2 asynchronous motors M11, M12. The delivery power system equipment data are $: \mathrm{T}_{1}, \mathrm{~T}_{2}$ transformers $110 \mathrm{kV} / 6 \mathrm{kV} ; \mathrm{T}_{3}, \mathrm{~T}_{4}, \mathrm{~T}_{5}$ and $\mathrm{T}_{6}$ transformers $6 \mathrm{kV} / 0,4 \mathrm{kV}$; busbar 3, busbar 4, busbar 5, busbar 6 and busbar $7-6 \mathrm{kV}$; motor $16 \mathrm{kV}-8 \mathrm{MW}$; motor 2 $6 \mathrm{kV}-2 \mathrm{MW}$; motor $36 \mathrm{kV}-500 \mathrm{MW}$; motor 4, 5, 6, 7 and $86 \mathrm{kV}-1,75 \mathrm{MW}$. The $8 \mathrm{MW}$ synchronous motor with rotor excitation is used for an air compressor drive, the $2 \mathrm{MW}$ asynchronous motor with short-circuit rotor is used for an oxygen compressor drive and a the $500 \mathrm{~kW}$ asynchronous motor with short-circuit rotor is used for a piston oxygen compressor drive.

The supply of station 1 is made through cells 5 and 7 and the reactance coils 1 , respective 2 . These reactance coils have the role of limiting the short-circuit currents which can appear downstream of them but also to maintain a normal voltage level at the terminals of the transformation station upstream of the coils, in case of short circuit in the network, in order not to stop other circuit motors in the main station, through the minimum voltage or maximum current protection reaction.

Station 1 comprises 8 cells with two three-phase bus systems and has $26 \mathrm{kV} / 0.4 \mathrm{kV}$ transformers that supply the $0,4 \mathrm{kV}$ buses 8 and 9 . Station 2 comprises 11 cells with 3 threephase bus system. Station 2 has two longitudinal couplings in cells 5 and 7 and has 2 $6 \mathrm{kV} / 0.4 \mathrm{kV}$ transformers that supply the $0,4 \mathrm{kV}$ buses 10 and 11 . 


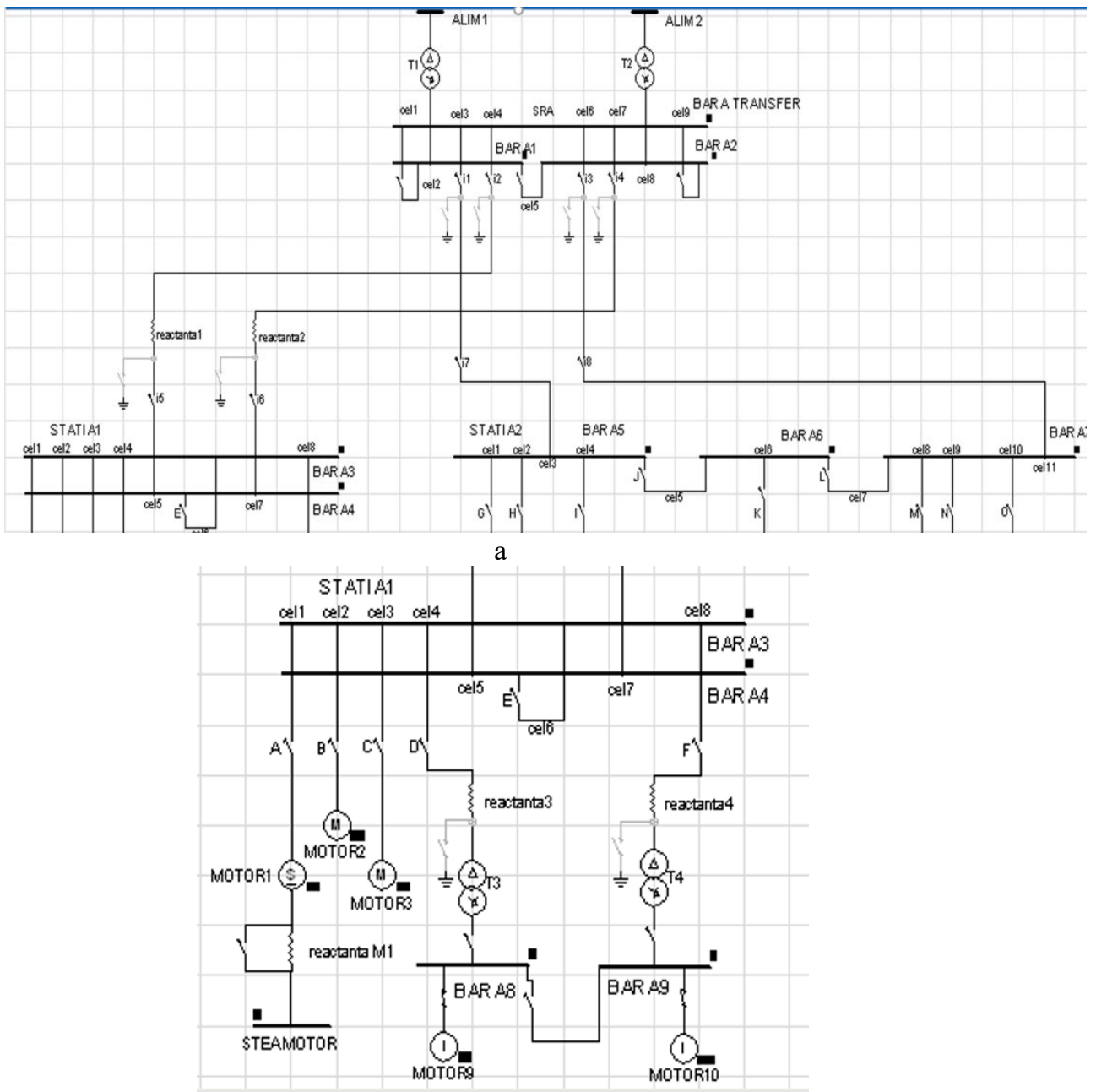

b

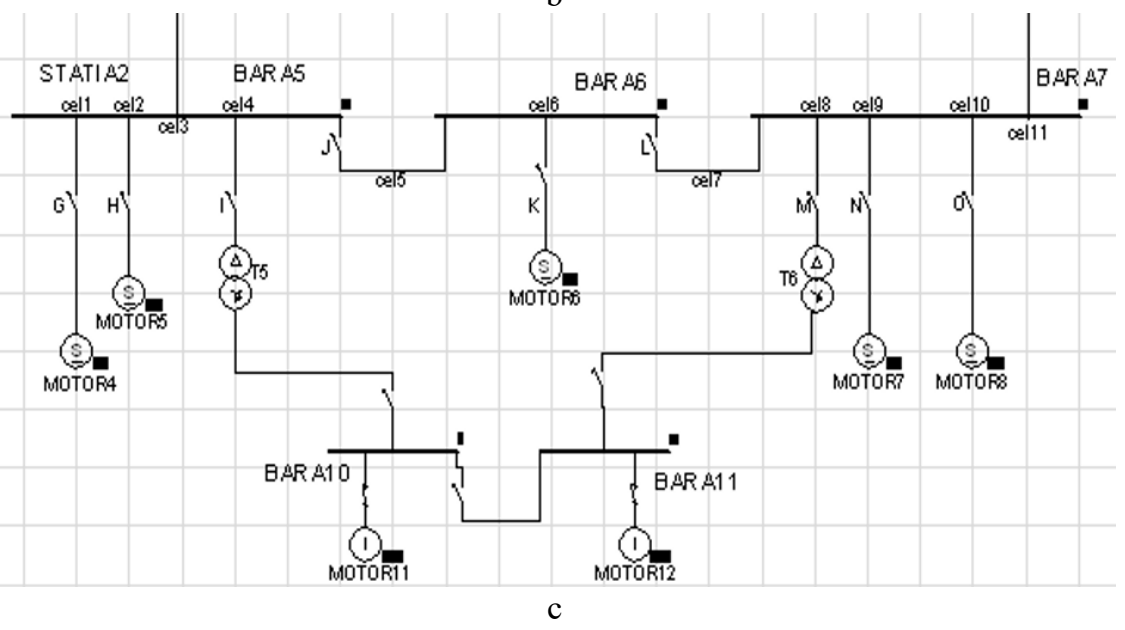

Fig. 1. Power supply of the analysed delivery system with important consumers: main supply station (a), substations - Station 1 (b), Station 2 (c). 


\section{Conducting the short-current analysis}

The essential consummers power supply system needs profesional power systems computer design software to be used, starting with the design phase, but also during the exploitation and maintainance phase $[9,10]$.

Edsa program is a professional software with more than fifty modules/software programs special used for design, analysis, simulation of the electric grid operation and power systems state.

Edsa set of tools are used for modeling and computing the network state, which allow solving of the electrical systems safety, efificiency, quality or reliability problems. It covers an important area in the most required industrial application for big power consummers like: electric power transport, electric power delivery, electric power plants, electric power industrial systems. The electric network schematic is easy to draw, which allow to conduct complex simulations and monitoring of the analyzsed power systems.

It also contains an optional module for the short-circuit current analysis. This option helps us to study the failures/defects can appear in the electric distribution networks such as: three-phase short circuits, single-phase short circuits, isolated two-phase short-circuits, two-phase short-circuits to ground, interruption faults.

Edsa program calculates the current in an electric power system during short-circuit conditions [4-6]. The information can be used to design relay protection systems, as well as fuse break conditions. The program calculates the values for direct, inverse and homopolar succession, short-circuit impedances using the impedances of the supply cables, the impedances of the coils, the impedances of the transformers, the contribution of the motors to the short-circuit current, the short-circuit power of the system.

From the program menu we access the "short circuit analysis" command. In the table 1 and table 2 are presented the results of the simulated three-phase short-circuit current and single-phase short-circuit current for study case system $0,4 \mathrm{kV}$ network, respective $6 \mathrm{kV}$ network. The tables present:

- the transient value $\mathrm{X} / \mathrm{R}$;

- $\quad$ the aperiodic component of the short-circuit current Idc (A);

- $\quad$ the periodic component Isym (A);

- $\quad$ the resulting short-circuit total current Iasym (A).

Iasym short-circuit current results from the composition of the two components Idc and Isym.

Table 1. Results of the simulated short-circuit for the $0,4 \mathrm{kV}$ network.

\begin{tabular}{|l|c|c|c|c|c|c|c|c|}
\hline \multicolumn{4}{|c|}{ Results $0,4 \mathrm{kV}$} & \multicolumn{3}{c|}{ Three-phase short circuits } & \multicolumn{2}{c|}{ Single-phase short circuits } \\
\hline Bus & $\begin{array}{c}\text { Voltage } \\
(\mathrm{V})\end{array}$ & $\mathrm{X} / \mathrm{R}$ & $\begin{array}{c}\text { Isym } \\
(\mathrm{A})\end{array}$ & $\begin{array}{c}\text { Idc } \\
(\mathrm{A})\end{array}$ & $\begin{array}{l}\text { Iasym } \\
(\mathrm{A})\end{array}$ & $\begin{array}{c}\text { Isym } \\
(\mathrm{A})\end{array}$ & $\begin{array}{c}\text { Idc } \\
(\mathrm{A})\end{array}$ & $\begin{array}{c}\text { Iasym } \\
(\mathrm{A})\end{array}$ \\
\hline BARA8 & 429 & 5.317 & 21376 & 16742 & 27478 & 24079 & 16823 & 29200 \\
\hline BARA9 & 427 & 5.655 & 25266 & 20502 & 29450 & 26454 & 18697 & 28700 \\
\hline BARA10 & 418 & 4.639 & 19904 & 14301 & 24659 & 20168 & 8140 & 21700 \\
\hline BARA11 & 419 & 4.64 & 20587 & 14794 & 25587 & 20421 & 8185 & 22000 \\
\hline MOTOR9 & 429 & 5.01 & 19168 & 7140 & 20450 & 20175 & 8163 & 21388 \\
\hline MOTOR10 & 427 & 5.25 & 20199 & 8280 & 21849 & 20482 & 8280 & 22448 \\
\hline MOTOR11 & 418 & 4.19 & 19015 & 7023 & 19607 & 19088 & 7102 & 19852 \\
\hline MOTOR12 & 419 & 4.21 & 20675 & 15152 & 25647 & 7157 & 20553 & 20551 \\
\hline
\end{tabular}


Table 2. Results of the simulated short-circuit for the $6 \mathrm{kV}$ network.

\begin{tabular}{|c|c|c|c|c|c|c|c|c|}
\hline \multicolumn{4}{c|}{ Results $6 \mathrm{kV}$} & \multicolumn{2}{c|}{ Three-phase short circuits } & \multicolumn{2}{c|}{ Single-phase short circuits } \\
\hline Bus & $\begin{array}{c}\text { Voltage } \\
(\mathrm{V})\end{array}$ & $\mathrm{X} / \mathrm{R}$ & $\begin{array}{c}\text { Isym } \\
(\mathrm{A})\end{array}$ & $\begin{array}{c}\text { Idc } \\
(\mathrm{A})\end{array}$ & $\begin{array}{c}\text { Iasym } \\
(\mathrm{A})\end{array}$ & $\begin{array}{c}\text { Isym } \\
(\mathrm{A})\end{array}$ & $\begin{array}{c}\text { Idc } \\
(\mathrm{A})\end{array}$ & $\begin{array}{c}\text { Iasym } \\
(\mathrm{A})\end{array}$ \\
\hline T1 & 110000 & 5.908 & 659 & 577 & 525 & 565 & 438 & 715 \\
\hline T2 & 110000 & 6.626 & 903 & 795 & 525 & 610 & 476 & 774 \\
\hline BARA1 & 6274 & 6.271 & 11252 & 9642 & 14816 & 25682 & 22344 & 34000 \\
\hline BARA2 & 6400 & 7.215 & 15157 & 13869 & 20270 & 32365 & 29629 & 43200 \\
\hline BARA3 & 6274 & 5.551 & 5253 & 4218 & 6609 & 6261 & 4849 & 7700 \\
\hline BARA4 & 6400 & 10.88 & 11801 & 12503 & 15131 & 9723 & 8508 & 11300 \\
\hline BARA5 & 6274 & 6.219 & 11233 & 9586 & 14764 & 25390 & 19842 & 32200 \\
\hline BARA6 & 6400 & 7.135 & 15126 & 13772 & 20179 & 31921 & 25620 & 40300 \\
\hline BARA7 & 6400 & 7.133 & 15128 & 13773 & 20182 & 31933 & 25624 & 40300 \\
\hline REACTOR1 & 6274 & 6.231 & 11240 & 9601 & 10283 & 25533 & 21031 & 33000 \\
\hline REACTOR2 & 6400 & 7.172 & 15144 & 13821 & 11320 & 32157 & 27553 & 41700 \\
\hline MOTOR1 & 6400 & 10.94 & 11810 & 12534 & 15151 & 9708 & 8424 & 11200 \\
\hline MOTOR3 & 6400 & 10.62 & 11736 & 12347 & 14991 & 6252 & 4824 & 7700 \\
\hline MOTOR2 & 6274 & 5.544 & 5249 & 4212 & 6601 & 9667 & 8335 & 11100 \\
\hline MOTOR4 & 6274 & 6.135 & 11147 & 9447 & 14605 & 24761 & 18219 & 30700 \\
\hline MOTOR5 & 6274 & 6.135 & 11147 & 9447 & 14605 & 24761 & 18219 & 30700 \\
\hline MOTOR6 & 6400 & 6.968 & 14966 & 13484 & 19753 & 30945 & 23042 & 38000 \\
\hline MOTOR7 & 6400 & 6.967 & 14969 & 13485 & 19870 & 30957 & 23045 & 38000 \\
\hline MOTOR8 & 6400 & 6.967 & 14969 & 13485 & 19870 & 30957 & 23045 & 38000 \\
\hline T3 & 6274 & 5.548 & 5252 & 4216 & 5084 & 6260 & 4848 & 7700 \\
\hline T4 & 6400 & 10.84 & 11797 & 12487 & 10336 & 9721 & 8504 & 11300 \\
\hline T5 & 6274 & 6.208 & 11230 & 9574 & 11208 & 25374 & 19822 & 32100 \\
\hline T6 & 6400 & 7.114 & 15122 & 13652 & 14885 & 31910 & 25592 & 40300 \\
\hline
\end{tabular}

\section{Safety and protection for the power essential consumers}

The analyzed results for the short-circuit calculation from Tables 1 and 2 are presented in the Figures 2, 3. These results allows to the specialists to propose and implement a new advanced protection system to improve the safety, replacing old equipments with the new advanced one. The improvements and optimizations made in the $6 \mathrm{kV}$ network are:

1. Replacement of the old breakers that have decades of operation with the new ones of Siprotec Siemens type;

2. Complete replacement of the cells in the station;

3. Replacement of the small rotor excitation of the $8 \mathrm{Mw}$ motor with static excitation;

4. Installation of A-isometer devices in the motor cell, devices that consist in monitoring the insulation of the cables connecting the motor breaker to the motor.

The Siprotec family is part from a series of innovative devices with protection and numerical control, open communication interface for remote control and setting of remote parameters, ergonomically designed user interface and highly flexible functionality. The devices use digital measurement techniques. Numerical signal processing ensures high 
accuracy of measurements and their dynamic stability, which determine a high degree of security of the protection response, as well as handling of harmonics and transient regimes.

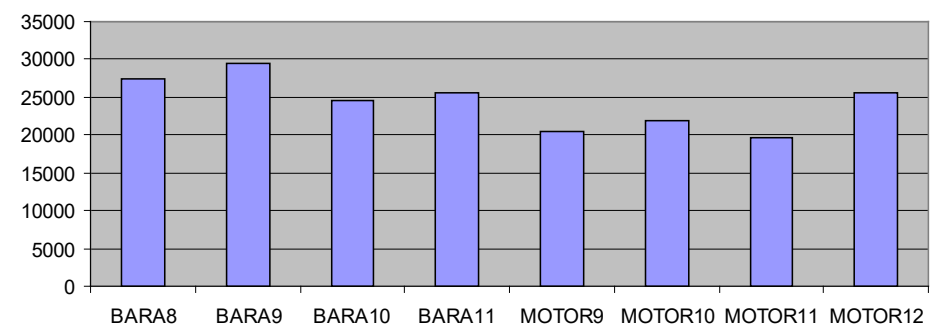

a

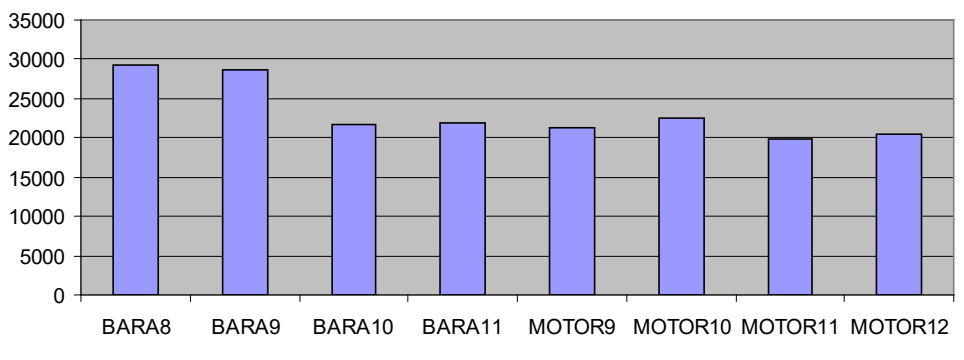

b

Fig. 2. Short-circuit calculation for $6 \mathrm{kV}$ network, three-phase current (a), single-phase current(b).

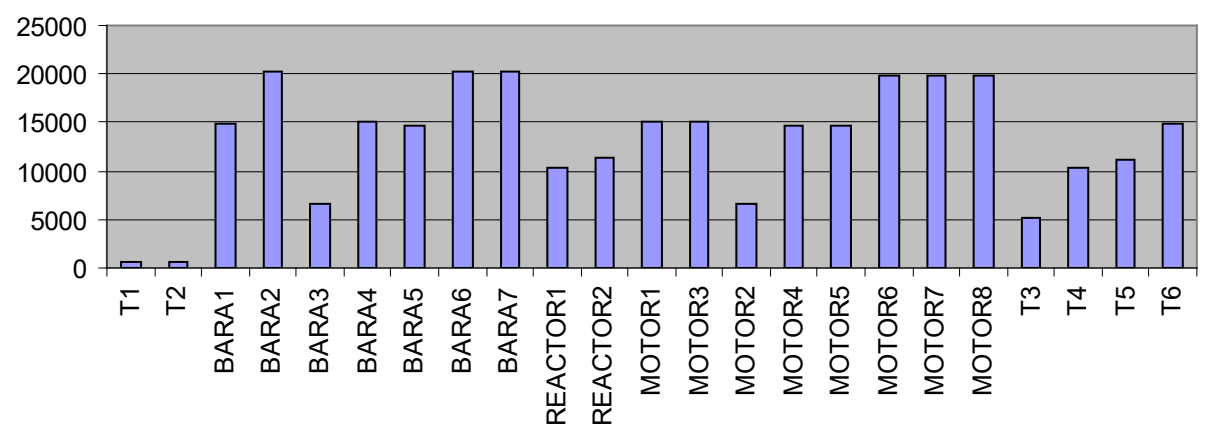

a

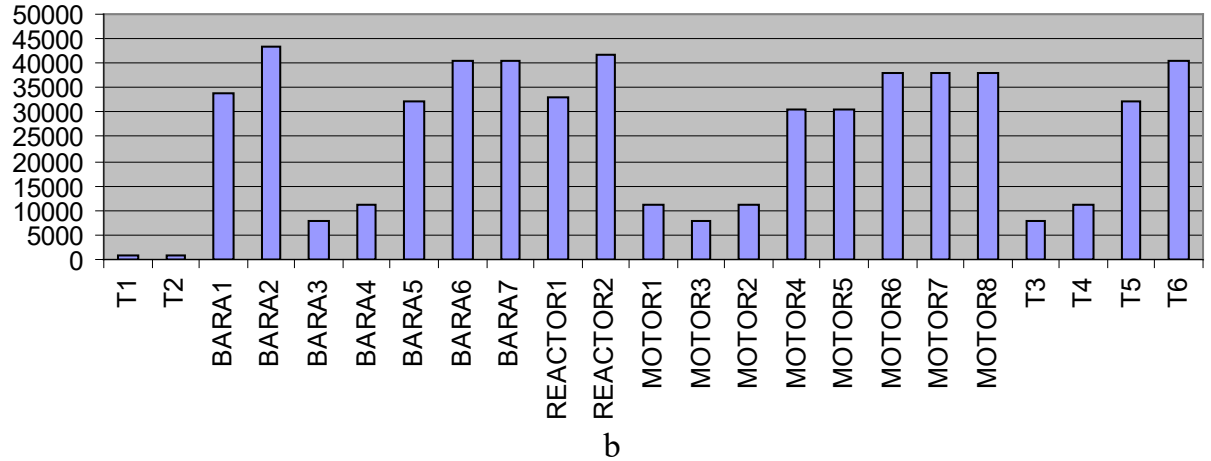

Fig. 3. Short-circuit calculation for $0,4 \mathrm{kV}$ network, three-phase current (a), single-phase current(b). 
The techniques of digital filtering and dynamic stabilization of the measured values determine a high degree of security when triggering the protection response. Device errors are quickly recognized and signaled by integrating a self-monitoring routine. The fall of protection during a network failure is almost entirely ruled out. You can choose devices with separate protection and control functions

This advanced device has the following functions available:

- protection and remote control functions in separate equipment;

- protection devices with the ability to control the breaker through the communications interface;

- devices with combined functions which, in addition to the protection functions of the device, offer numerous local remote control functions for several switching devices which include extensive control functions.

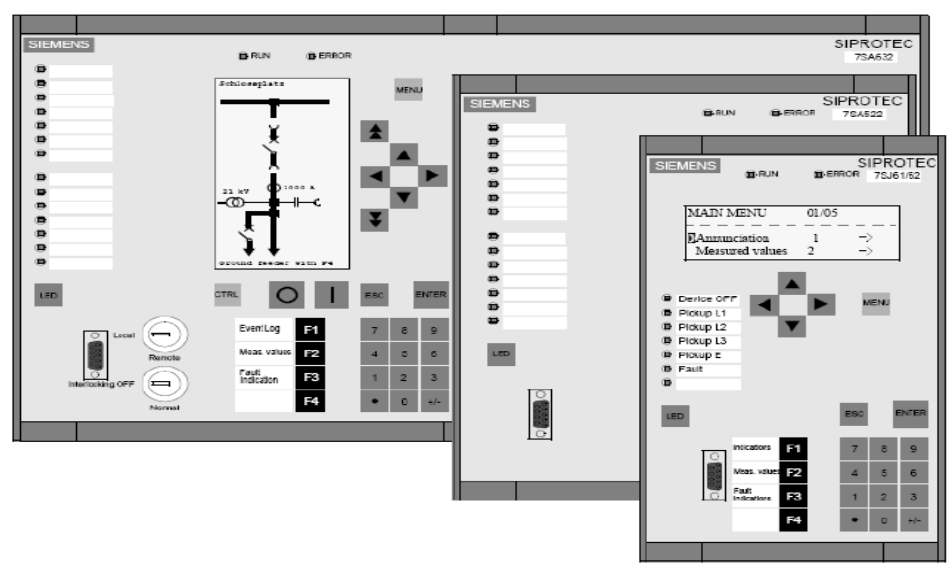

a

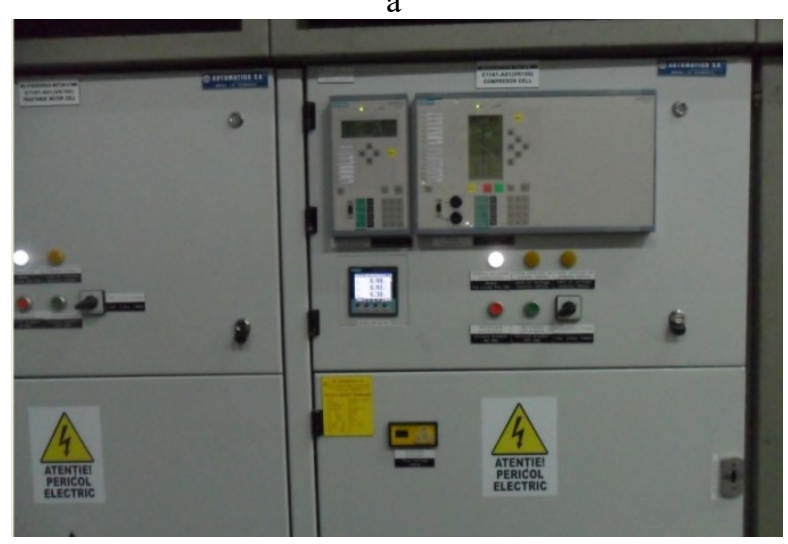

b

Fig. 4. Siprotec Siemens numerical device for protection, remote control and communication in the analyzed network, software interface control (a), device local control (b),

Communication of the Siprotec devices with the central control system is fully having the requirements of modern communication technologies. They have interfaces that allow integration with high-level remote control centers, comfortable setting of parameters and operation via a local PC or via a modem connection. The devices support international open communications standards: PROFIBUS FMS, PROFIBUS DP, IEC 60870-5-103, DNP 3.00 Level 2, MODBUS ASCII / RTU, Ethernet connection according to IEC 61850. 
Siprotec devices can operate in two ways (Figure 4):

- via the control panel on the device;

- through the DIGSI computer software interface, which is connected locally to the operator interface of the device or through a modem and service interface.

The control panel of the devices, ergonomically designed and easy to read, allows the execution of the local control operations, the realization of the sets of the device parameters and the display of all the information necessary for the operation. The control panel is equipped with either a full graphic display or a 4-row display, depending on the device mode.

\section{Conclusions}

Safety analysis is one of the main objectives for the scientist in the power system domain. To maintain safety of the power systems to the high standards imposed it is a continuous process. In order to achieve this goal detailed power system modeling and simulation is needed. With the help of the professional software Edsa we conduct the safety analysis for a power delivery real system with essential consumers, which must be continuous power supplied. The two levels voltage networks $6 \mathrm{kV}$ and $0,4 \mathrm{kV}$ were first modelled, which brings the possibility to use Edsa specialized modules like power flow analysis and shortcircuit analysis and to compute the network currents flow, while short-circuit are simulated.. In this paper the results of the short-circuit analysis, for all the network buses supplying esential consumers, are presented and are used for the system safety increasing. The delivery power system safety get big improvement by replacing old protection equipments with the new advanced Siprotec Siemens devices and by the complete replacement of the cells in the $6 \mathrm{kV}$ electric stations, which gives very important safety benefits.

\section{References}

1. R. C. Dugan, H. W. Beaty, M. F, McGranagham, Electrical power systems quality (New York: Mc.Graw-Hill, 39-80,1996)

2. M. Dumitrescu, Power Systems (Edited on Didactica and Pedagogica, Bucuresti, 2002)

3. M. Dumitrescu., Efficiency and Reliability on Power Systems (Edited on Didactica and Pedagogica, Bucuresti, 2003)

4. *** IEC 61000-3-7, Part 3: Limits - Section 7: Assessment of emission limits for fluctuating power in MV and HV power systems (2000)

5. *** IEEE P1366, Trial Use Guide for Electric Power Distribution Reliability Indices, Working Group on System Design, Draft 5, Ian. (2001)

6. $* * *$ IEC 61400-21, Measurement and assessment of power quality characteristics of grids (2005)

7. N. Mohan, T. M. Undelan, W.P. Robbins, Power systems, applications and design (2nd Edition New York, Wiley \& Sons, 102-152, 2005)

8. M. Saied, Measures for the supply efficiency in distribution network, INT.J.Elect. Power Energy Systems, vol 23, 427- 434, (2001)

9. M. Bazrafshan, N. Gatsis, Comprehensive modelling of three phase distribution systems via the bus admittance matrix. IEEE Trans. Power Syst. 33, 2015-2029, (2018).

10. A. Garces, A linear three phase load flow for power distribution systems. IEEE Trans. Power Syst. 31, 827-828, (2016)

11. *** IEC 60870-5-103 Transmission Protocols - Companion standard for the informative interface of protection equipment

12. *** IEC 61850 Communication protocols for intelligent electronic devices at electrical substation 